\title{
Art and Culture in Chinese Corporate Responsibility: A Qualitative Enquiry
}

\author{
Barend Pieter Venter*, Baoyi Guo, Yan Chen \\ Beijing Normal University-Hong Kong Baptist University United International College, Zhuhai, China \\ Email: ^benpiet@uic.edu.hk, bronniekwok@gmail.com,yanchan1997c@gmail.com
}

How to cite this paper: Venter, B. P., Guo, B. Y., \& Chen, Y. (2020). Art and Culture in Chinese Corporate Responsibility: A Qualitative Enquiry. Sociology Mind, 10, 70-81. https://doi.org/10.4236/sm.2020.102006

Received: January 13, 2020

Accepted: March 23, 2020

Published: March 26, 2020

Copyright $\odot 2020$ by author(s) and Scientific Research Publishing Inc. This work is licensed under the Creative Commons Attribution International License (CC BY 4.0).

http://creativecommons.org/licenses/by/4.0/ (c) (i) Open Access

\begin{abstract}
This paper investigates the motivations and the forms of practicing CSR in art and culture in China, which is increasingly conducted but still not sufficiently studied. According to cases and interviews, philanthropic responsibility, business results contribution, and corporation reputation enhancement are some core motivations driving corporations in China to practice CSR in art and culture, and they positively correlate with involvement levels in art and culture resources. However, corporate nature and industrial nature own stronger power in corporation CSR decision-making under the instructions of the Chinese government. Therefore, corporations are recommended to ponder their motivations and involvement level of art and culture resources before their actions, and new research perspectives and methodology of CSR studies pertaining to the business context in China deserve a revision as well.
\end{abstract}

\section{Keywords}

CSR Practice, CSR Measurement, CSR Motivation, Art Business, Cultural Industry

\section{Introduction}

The call for social responsibility in business practice is not new, and the term "corporate social responsibility" (CSR) is in wide use. Nonetheless, as a component of CSR practice, corporation engagement in art and culture activities, namely "CSR in art and culture" in this paper, is increasingly practiced but still not sufficiently studied.

Originally, ancient Chinese, Egyptian, and Sumerian writings delineated rules for commerce to facilitate trade and ensure that the interests of the wider public were considered (Werther \& Chandler, 2014). The modern concept of CSR first emerged in the 1950s, and was encapsulated in Howard R. Bowen's publication 
Social Responsibilities of the Businessman (Beal, 2014). In the 1970s, Milton Friedman formulated the "shareholder primacy perspective" of social responsibility by arguing that increasing profit is the social responsibility of business. Later, management and marketing scholars debated a new "stakeholder primacy perspective" of CSR, which is an expanded notion of a corporation's obligations to all relevant stakeholders, not just owners (Munilla \& Miles, 2005).

The 1990s represent a shift in CSR, away from individual business action to a global sustainability consensus, because the United Nations formulated its Global Compact, which can also be gleaned from the debate between the shareholder primacy and stakeholder primacy perspective of CSR. After the dawn of the new Millennium, the motivation for practicing CSR has become more operation-oriented and future-oriented in the view of business ethics and strategic management. Ghillyer (2013) states that CSR is an action of management with a conscience in a business ethics perspective while Porter and Kramer (2011) define CSR as the proactive integration of a social dimension into corporate strategic planning. Besides, in more recent research, CSR is also regarded as a presentation form of corporate-owned social impact measurement approach, which belongs to corporate initiatives as one of the social impact evaluators (Durand, Rodgers, \& Lee, 2019: pp. 6-11).

Compared to CSR practice worldwide, corporations in China seem to be behind the curve. The concept of CSR was introduced to China in 1996 (Southern Weekly, 2018), but it was not until 2004 that China's government, corporations, and citizens started to pay attention to CSR because of a number of business scandals surfacing at that time. Through around two decades of development, CSR practices in China have developed its three characteristics so far: 1) government and policy-oriented, 2) corporate nature affected, and 3) single CSR focus. Specifically, many corporations in China focus on "going green" or volunteer activity. As to the industrial perspective: finance, smelting, pharmaceutical manufacturing, electric power, and automotive manufacturing have become the top five industries that release CSR reports in China (Southern Weekly, 2018).

To narrow down, CSR in art and culture comes from business intervention in art or culture-related activities, a practice that is quite common in the Western world. Historically, the Medici family pioneered a path of art patronage during the Renaissance, and the US corporation International Business Machines (IBM) started collecting artworks in 1939 (Howarth, 2014), forming the prelude to modern business involvement in art and culture. Similar involvement became apparent in China since the 1980s, the time of the Reform and Opening Up policy. Within a fast developing economy, Chinese corporations not only collected art or sponsor art events as their Western counterparts do, but also founded their own auction companies, art museums and, most importantly, the cultural business such as the China POLY Group Co., Ltd.

CSR in art and culture is generally regarded as the deployment of and support for art and cultural strategies to achieve positive change within corporations 
(Stern, 2015). Similar practices, such as "art supporting activity" (Shiseido, 2020), corporate philanthropy towards the art (O'Hagan \& Harvey, 2000), corporate support for artistic and cultural activities (Leclair \& Gordon, 2000), and collaborative development of long-term formats and partnerships in corporations' international cultural commitments (Girst et al., 2018) are found. However, the exact scope of "art and culture" remains a matter of debate and ambiguity. Firstly, corporations may not state clearly whether their artistic and cultural activities belong to CSR practices or not, especially in large-scale corporations with complicated art and culture intervention structures. Secondly, CSR practices conducted with art and cultural elements may not be regarded as CSR in art and culture. Thirdly, a new relationship between CSR and art and cultural resources has emerged whereby art and culture are used as a form of CSR presentation. To complicate matters more, forms of CSR in art and culture are more confusing in China owing to its complex cultural context, extensive art and cultural resources, and the infancy of CSR practice.

Therefore, to delimit the scope of "art and culture" for the focus of this paper, the term "art and culture" should not be just for the sake of their literal meanings but serve as a kind of resource. Bear in mind that both the term "culture" as well as "art" are some of the most complicated words in the English language (Throsby, 2001). Since artistic and cultural resources form the core of the cultural economy, this paper adopts the cultural domains as defined in UNESCO's "Framework for Cultural Statistics Domains" to better capture the breadth and diversity of artistic and cultural resources. There are six domains in this framework, including cultural and natural heritage, performance and celebration, visual arts and crafts, books and press, audio-visual and interactive media, and design and creative services. Additionally, this framework also provides a perspective centering on the interplay between culture and economy (UNESCO Institute for Statistics, 2009; UNESCO, 2013).

We wanted to know what the current state of art and culture CSR practice in China looks like, and what motivates this practice. To answer these questions, we conducted a literature review and a qualitative enquiry based on concepts identified in literature.

\section{Literature Review}

Literature on CSR is vast and complex (Malloch, 2013, p. xiv), but relatively few papers directly discuss the issue of CSR in art and culture. Our literature review was therefore divided into three parts: first, indicator-based measurement of CSR, which summarizes substantive indicators of CSR guidelines and measurements and thereby, outlines the position of CSR in art and culture; second, motivations of corporations that practice CSR; and third, forms of business intervention in art and culture resources.

\subsection{Indicator-Based Measurement of CSR}

CSR is widely found in the academic realms of marketing (Pirsch, Gupta, \& 
Grau, 2007), corporate reputation (Caruana \& Chircop, 2000; Dowling, 2016), public relations, law and ethics (Shum \& Yam, 2011; Ghillyer, 2013; Carroll, 2016), and management strategy (Porter \& Kramer, 2011), causing it to have different emphases. Previous academic arguments classify CSR measurement approaches into three themes: 1) managerial survey, 2) indicator-based approach, and 3) expert evaluation. However, the different measurements have been complicated owing to the ambiguity and contradictory nature of CSR concept(s). In order to maintain theoretical coherence in this paper, substantive indicators of the indicator-based approach are adopted to deal with single, quantifiable numbers or events (Ray, 2013).

Substantive indicators of CSR practices first have to adopt a commonly accepted guideline to focus on its activities (Ray, 2013). Most CSR guidelines are formulated by international and industrial organizations with different emphases:

- Global Reporting Initiative sustainability report.

- United Nation's Sustainable Development Goals report on sustainable future.

- International Organization for Standardization socially responsible business operations.

- Social Accountability International focusing on the workplace.

These recognisable CSR guidelines have found a broad consensus worldwide, and are also found in China's business environment. However, it is noted that CSR guidelines in China are offered by national instructions, think tanks, and stock exchanges, from adapting the world consensus to local conditions. Therefore, they are more national strategy-, government policy-, and law-oriented than industry-driven or self-regulated. Government, rather than private sector, drives CSR measurement in China.

Under conditions such as these, substantive CSR indicators in China vary from the usual world practice. Generally speaking, financial institutions and third party inspection agencies are the leading CSR measurement providers in the world, by using the methodology of rating and ranking corporations' CSR performance such as the Dow Jones Sustainability Index and FTSE4 Good Index Series (Ray, 2013). In addition, an ESG (environmental, social, governance) model of substantive indicators is widely used as well, especially in the contexts of accounting and consulting corporations for their investment valuations and financial performance ramifications (Durand, Rodgers, \& Lee, 2019: p. 9). Similar methodologies are developed in China, instructed by Guidance on Social Responsibility Reporting and responding to the national track in promoting balanced economic, political, cultural, social, and ecological progress. For example: Rankins CSR Ratings, CBN-Aegon Responsibility Index, Material and Quantitative Indicators and the latest "Social Value 99" Assessment. Moreover, a mature Hang Seng Corporate Sustainability Index is applicable in both Mainland China and Hong Kong.

A summary of substantive indicators pertaining to the aforementioned CSR 
guidelines and measurements gives a clear picture of popular indicators in the world and China respectively. Both of them mainly concern 1) code of business conduct, corporate governance, and profitability in the economic dimension, 2) operational eco-efficiency, environmental reporting and pollution in the environmental dimension, and 3) labor rights, corporate citizenship and philanthropy, and consumer issues in the social dimension. It should be mentioned that indicators made in China lean towards risk and crisis management, business strategy, supply chain management and product stewardship rather than tax strategy, biodiversity, climate strategy, children rights, human capital development, and talent attraction. However, regarding poverty and hunger alleviation, to which China's government attaches great importance as far as CSR guidelines are concerned, do not belong to a measurable indicator. Supporting art and culture does not attract any particular emphasis either, and it is only regarded as a part of "corporate citizenship and philanthropy". Simply put, compared with the eye-catching practice of CSR in art and culture, its attention and relevant research have not been taken seriously so far.

\subsection{Motivations for Corporations to Practice CSR}

Leclair and Gordon (2000) pointed out that the critical difference between CSR and non-CSR appears to be an elevated sense of social responsibility. Apart from the idealised discussion of a pure sense of social responsibility as a CSR motivator, motivations of corporation practice CSR can be found in the shared realms of business ethics and strategic management.

The most classical CSR theory in business ethics realm is the CSR pyramid (or hierarchy), which was coined by Archie B. Carroll in 1991 and has provided structure to corporate CSR from a starting step to the ultimate goal, i.e. economic responsibility, legal responsibility, ethical responsibility, and philanthropic responsibility. On the other hand, as to strategic corporate CSR, neoliberal, neo-Keynesian, and radical political economy approaches are three discernible schools of thought (Malloch, 2013: p. ix). The neoliberal approach, based on the Friedman Doctrine in 1970, tends to see CSR fundamentally as a set of voluntary policies, codes, or guidelines of corporate engagements in open and free completion without deception or fraud (Malloch, 2013: p. vii). Under the neoliberal assumption, CSR is also seen as an essential insurance strategy to minimise risks from negative government intervention, adverse media coverage, and consumer or stockholder backlash to corporate behavior (Malloch, 2013: p. viii; Strandberg, 2016). In contrast, the neo-Keynesian approach recognises the active role of corporate stakeholders. It suggests that, for effective and meaningful CSR, only the interests of a range of stakeholders other than shareholders need to be taken into account by corporations (Malloch, 2013: p. xiii). Stakeholders such as customers, active investors, non-profit organizations, and supra-national entities are the main pressure groups pushing corporations to practice CSR (Cuervo-Cazurra, 2018), and in China, the power of pressure groups is somewhat stronger (Southern Weekly, 2018). Besides, the radical political economy ap- 
proach is more critical; its supporters openly reject voluntary CSR and advocate an alternative strategy that is generally described as "coercive corporate accountability" (Malloch, 2013: p. ix).

Key issues and debates of CSR also fall into brand differentiation and attention diversion. The former helps corporations to separate them from the intense market competition in consumers' mind (Malloch, 2013: p. xi) and the latter allows corporations to draw consumers' attention away from their perceived negative impacts (Malloch, 2013: p. xii). As for these phenomena, Rangan, Chase and Karim (2015) gave critiques to many corporations who were wrongly seeking CSR outcomes of mitigating risks, enhancing reputation, and contributing to business results, which should be the spillover created by CSR rather than a reason for being CSR. Nonetheless, the chase for CSR spillover is universal in corporate interventions in art and culture related activities because of the undoubted positive externalities of art and culture and their positive impacts on stimulating the economy (Kuti \& Marschall, 1992). Within, commonly pointed out by O'Hagan and Harvey (2000), Leclair and Gordon (2000), Stern (2015), and Herranz-de-la-Casa, Manfredi-Sánchez and Cabezuelo-Lorenzo (2015), the quest for corporation reputation enhancement is motivating corporate practice CSR in art and culture. However, in China, this quest is less obvious, while political direction is more visible as key motivation for corporations to practice CSR.

\subsection{Forms of Business Intervention in Artistic and Cultural Resources}

The forms of business intervention in artistic and cultural resources are complex and varied, and a likert-type scale can well be used to differentiate between these forms of interventions, ranging from "not involved" to "deeply involved".

Initially, business interventions without any involvement in artistic and cultural resources can be said to be "not involved", while business with some interventions with artistic and cultural resources can be "simply involved". Relevant examples include activities such as art collaboration in product design, the use of artistic and cultural resources for promotion or presentation activity, and the purchase of small-scale artworks for office decoration. When corporations become "moderately involved", more energy and cost are required, and they start seeking a synergy created by intervention in artistic and cultural resources. Activities such as organising art or culture exhibitions, collecting large-scale artworks, and becoming involved in patronage or bequests are typical examples. However, the popularity of "moderately involved" is far different in the west and China due to historical reasons. To trace back, modern western family trusts such as the Rockefeller and Guggenheims instilled artistic and cultural values in their businesses much earlier than Chinese corporations have done, with the result that they have collected more impressive collections and feature as core components in many world-class museums today. Besides, taxation also plays a role in encouraging or discouraging patronage, endowments, and suchlike beha- 
viors. According Liu (2017), the immature systems of tariff, sales tax and personal income tax pertaining to artworks have severely decelerated the development progress of art donations in China while a variety of tax incentives have been introduced to inspire donations in the west (Yates, 2016).

Based on the "moderately involved", corporations can be said to be "deeply involved" when they integrate artistic and cultural resources with their business resources, such as building art or cultural facilities, offering sponsorships, forming two-way exchanges of skills and knowledge through partnerships, and conducting corporate collections, corporate museums, and historical archives as investment (Herranz-de-la-Casa et al., 2015). In addition, the highest level of involvement is found in organic business intervention in artistic and cultural resources with precise project design, patient management, and long-term planning. Such giant and vast interventions are common in the forms of 1) setting up art or culture funds, awards, and competitions, 2) founding of a cultural business sector, and 3) preserving and conserving cultural heritage.

The literature above shows us the various types of involvement in art and culture as far as CSR is concerned, but it mainly addresses these practices and what motivates them in Western countries, while information about the motivation behind CSR and its relationship to art and culture in China is very scarce or nonexistent.

\section{Methodology}

In order to answer our research question, we conducted a qualitative enquiry to establish the motives for, and practice of, CSR in the art and culture in China.

The enquiry proceeds in three steps. First, we used the constructs identified in our literature review to study a wide range of official corporate websites and CSR reports of major corporations in China as sample cases, capturing an overall picture of CSR practice in China. Second, we then conducted interviews with fifty judgment-sampled professionals from the areas of 1) art or cultural management, 2) business administration (especially business ethics and strategic management), 3) marketing, public relations, or advertisement and 4) public service, social service, or charity, in the field to establish their views of the practice of CSR in art and culture in the Chinese context. Finally, we tested some of their findings among random-sampled members of the public, to see whether their actions were perceived in a cynical or sincere light.

To elaborate, in the first step, we selected one hundred Chinese corporations (include joint venture and foreign-invested corporations) from eleven industries to study their most updated official CSR statements and reports, focusing on how they define CSR practices and what type of CSR practices they have conducted. Specifically, the eleven industries are selected based on the industry classification of Hang Seng Corporate Sustainability Index, covering integrated enterprise, technology and information, real estate, consumer service, consumer goods manufacturing, finance, telecommunication, industrial manufacturing, energy, public utility, and raw material. In the second step, we set up two groups 
of interview questions to collect the professional viewpoints in terms of the motivations of corporations practice CSR in art and culture and their corresponding involvement levels of art and culture resources. In particular, we asked the professionals on whether and to what art and culture resources involvement extent the Chinese corporations practice CSR in art and culture out of economic responsibility, legal responsibility, ethical responsibility, philanthropic responsibility, risk mitigation, corporation reputation enhancement, business results contribution, and pure sense of social responsibility respectively. After getting viewpoints from the professionals, we selected and repeated some of the interview questions to the public, in the last step.

\section{Findings and Discussion}

Based on the information provided by official corporation websites and CSR reports, one hundred corporations from eleven industries report that most of them have practiced CSR in economic, environmental, and social dimensions, but only around one fifth (21 out of 100) have practiced CSR in the artistic and cultural sphere. To break down, those corporations are one from the integrated enterprise (China OCT Group), four from the technology and information industry (Tencent, Baidu, Canon (China), and Fuji Film (China)), two from the real estate industry (Times China and Vanke), six from the consumer service industry (China Southern Air, Artron Group, H. Brothers, China Guardian Auctions, Christie's (China), and Taikang Insurance), six from the consumer goods manufacturing industry (BMW Group (China), Aurora Group, Snow Beer, Suntory (China), Shiseido (China), and Sulwhasoo (China)), and two from the finance industry (China Mingsheng Bank and Zendai Group). Within, none of them practice CSR in art and culture out of legal responsibility and ethical responsibility, but many of them seek for philanthropic responsibility, business results contribution, and corporation reputation enhancement (Table 1).

In contrast, the interview results provide somewhat different outcomes. Our interviews show two phenomena: 1) corporations in China become moderately involved in artistic and cultural resources when they practice CSR in art and culture; 2) philanthropic responsibility, business result contribution, and corporation

Table 1. Number of CSR in art and culture practiced within one hundred Chinese corporations.

\begin{tabular}{cccc}
\hline & Moderately involved & Deeply involved & Organically involved \\
\hline Economic responsibility & 3 & 8 & 1 \\
Philanthropic responsibility & 1 & & 1 \\
Risk mitigation & 5 & 4 \\
Contribute to business results & 2 & 1 \\
Reputation enhancement & 1 & \\
Pure sense of CSR & & 1 & \\
\hline
\end{tabular}

Note: summarized by the authors in April, 2019 
reputation enhancement are the core motivations for corporations practicing CSR in art and culture in China. However, compared to our first-step study, there is no Chinese corporation practice CSR in art and culture out of ethical responsibility, and there are some scattered cases of corporations that practice CSR out of economic responsibility, risk mitigation, and pure sense of social responsibility surprisingly. For example, Tencent's "New Ethnomusicology Project" is operated out of economic responsibility, Christie's (China)'s looting of cultural property policy is set to mitigate risk, and Snow Beer's sponsorship of editing and publishing the monographs of "Ancient Chinese Architectural Knowledge Popularization and Inheritance Series" is conducted out of pure sense of social responsibility.

Furthermore, as to corporate nature, although state-owned and central-owned corporations have released $65 \%$ of total CSR reports together in the past decade in China (Southern Weekly, 2018), they seldom practice in art and culture areas. As to industrial nature, corporations in the technology and information industry, consumer service industry and consumer goods manufacturing industry are the top three industries of practicing CSR in art and culture in China, whereas most of them are privately run, joint venture and foreign-invested corporations.

\section{Conclusion and Future Research}

Deviations between interview results and real cases may be due to three reasons: 1) majority of people in China do not clearly understand CSR; 2) different corporate natures affect different involvement levels of CSR; 3) different industrial natures affect different emphases in CSR practices. Moreover, the differences between western and Chinese CSR traditions, cognitions, and evaluation methods do not result in an ideal outcome of this paper as well, but provide some valuable references for future research.

According to our interview results, both professionals and members of the Chinese public perceive that corporations in China practice CSR in art and culture out of ethical responsibility, philanthropic responsibility, business results contribution, and corporation reputation enhancement rather than economic responsibility, legal responsibility, risk mitigation and pure sense of social responsibility, and the relationship between such motivations and involvement levels of art and culture resources is positively correlated. However, compared to the real cases, CSR practices in China are mainly guided by government instructions, CSR in art and culture is not a significant focus, and no corporation practices CSR in art and culture out of ethical responsibility, showing partial applicability to the interview results in this paper and the passivity of Chinese corporations in practicing CSR to a certain extent. Additionally, the corporate nature and industrial nature of a corporation have substantial power in affecting CSR practices in China. In particular, corporate nature affects whether corporations in China practice CSR or not, and industrial nature affects which kind of CSR 
practice they do.

Consequently, in order to practice CSR in art and culture with beneficial outcomes in China, corporations are suggested to ponder their motivations and involvement level of art and culture resources before their actions. Also, they are suggested to involve art and culture resources at moderate or deep level, which may win favor from the public in a cost-effective way. As to future research, it will be valuable to study how corporate and industrial nature in China affects CSR practice in art and culture, and to what extent they are "merely" guided by government direction.

\section{Conflicts of Interest}

The authors declare no conflicts of interest regarding the publication of this paper.

\section{References}

Beal, B. D. (2014). Corporate Social Responsibility: Definition, Core Issues, and Recent Developments. Los Angeles, CA: SAGE. https://doi.org/10.4135/9781483388014

Carroll, A. B. (2016). Carroll's Pyramid of CSR: Taking Another Look. International Journal of Corporate Social Responsibility, 1, 1-8. https://doi.org/10.1186/s40991-016-0004-6

Caruana, A., \& Chircop, S. (2000). Measuring Corporate Reputation: A Case Example. Corporate Reputation Review, 3, 43-57. https://doi.org/10.1057/palgrave.crr.1540098

Cuervo-Cazurra, A. (2018). The Evolution of Business Groups' Corporate Social Responsibility. Journal of Business Ethics, 153, 997-1016.

https://doi.org/10.1007/s10551-018-3912-4

Dowling, G. R. (2016). Defining and Measuring Corporate Reputations. European Management Review, 13, 207-223. https://doi.org/10.1111/emre.12081

Durand, R., Rodgers, Z., \& Lee, S. (2019). Social Impact Assessment Strategy Report. Paris: HEC Paris Society and Organizations Center.

https://www.hec.edu/en/faculty-research/centers/society-organizations-center/think/so cial-impact-assessment-report

Ghillyer, A. (2013). Business Ethics Now (5th International Student ed.). New York: McGraw-Hill.

Girst, T., Laskowski, L., Bauer, S., Jennes, S., \& Fleischer, D. (2018). BMW Group Cultural Engagement. Munich: BMW Group Business, Finance and Culture Communications. https://www.bmwgroup.com/en/responsibility/culture.html

Herranz-de-la-Casa, J., Manfredi-Sánchez, J., \& Cabezuelo-Lorenzo, F. (2015). Latest Trends and Initiatives in Corporate Social Responsibility: A Communicational Analysis of Successful Cases of Arts and Culture in Spain. Catalan Journal of Communication \& Cultural Studies, 7, 217-229. https://doi.org/10.1386/cjcs.7.2.217_1

Howarth, R. S. (2014). A Brief History of Corporate Collecting. http://www.corporateartbrief.com/?p=20

Kuti, E., \& Marschall, M. (1992). Cultural Goods and Their Positive Externalities. World Futures, 33, 181-187. https://doi.org/10.1080/02604027.1992.9972280

Leclair, M. S., \& Gordon, K. (2000). Corporate Support for Artistic and Cultural Activi- 
ties: What Determines the Distribution of Corporate Giving? Journal of Cultural Economics, 24, 225-241. https://doi.org/10.1023/A:1007686500896

Liu, S. (2017). On the Reform and Perfection of Art Tax System in China. https://news.artron.net/20171031/n965234.html

Malloch, T. R. (2013). Foreword. In S. O. Idowu, N. Capaldi, L. Zu, \& A. Dasgupta (Eds.), Encyclopedia of Corporate Social Responsibility (pp. vii-xv). Berlin, Heidelberg: Springer Berlin Heidelberg.

Munilla, L. S., \& Miles, M. P. (2005). The Corporate Social Responsibility Continuum as a Component of Stakeholder Theory. Business and Society Review, 110, 371-387. https://doi.org/10.1111/j.0045-3609.2005.00021.x

O’Hagan, J., \& Harvey, D. (2000). Why Do Companies Sponsor Arts Events? Some Evidence and a Proposed Classification. Journal of Cultural Economics, 24, 205-224. https://doi.org/10.1023/A:1007653328733

Pirsch, J., Gupta, S., \& Grau, S. L. (2007). A Framework for Understanding Corporate Social Responsibility Programs as a Continuum: An Exploratory Study. Journal of Business Ethics, 70, 125-140. https://doi.org/10.1007/s10551-006-9100-y

Porter, M. E., \& Kramer, M. R. (2011). Creating Shared Value. Harvard Business Review. https://hbr.org/2011/01/the-big-idea-creating-shared-value

Rangan, K., Chase, L., \& Karim, S. (2015). The Truth about CSR. Harvard Business Review, January-February (1/2), 40-49. https://hbr.org/2015/01/the-truth-about-csr

Ray, S. (2013). CSR Measurement. In S. O. Idowu, N. Capaldi, L. Zu, \& A. Dasgupta (Eds.), Encyclopedia of Corporate Social Responsibility (pp. 716-721). Berlin, Heidelberg: Springer Berlin Heidelberg. https://doi.org/10.1007/978-3-642-28036-8 213

Shiseido (2020). Art Supporting Activity. https://www.shiseidogroup.com/beauty-art/support

Shum, P. K., \& Yam, S. L. (2011). Ethics and Law: Guiding the Invisible Hand to Correct Corporate Social Responsibility Externalities. Journal of Business Ethics, 98, 549-571. https://doi.org/10.1007/s10551-010-0608-9

Southern Weekly (2018). Ten Years of Southern Weekly's CSR Observation in China, the "Responsibility and Consensus Building" Conference Was Held in Beijing. http://www.infzm.com/contents/137897

Stern, L. E. (2015). Corporate Social Responsibility: The Arts. Washington DC: Animating Democracy. http://animatingdemocracy.org/sites/default/files/CSR Report FINAL.pdf

Strandberg, C. (2016). Risk Management's New Tool: Corporate Social Responsibility. Madison: Filene Research Institute. https://corostrandberg.com/wp-content/uploads/2016/05/risk-mitigation.pdf

Throsby, D. (2001). Economics and Culture. Cambridge, New York: Cambridge University Press.

UNESCO (2013). Creative Economy Report 2013 Special Edition: Widening Local Development Pathways. Paris: Author.

http://www.unesco.org/culture/pdf/creative-economy-report-2013-en.pdf

UNESCO Institute for Statistics (2009). The 2009: UNESCO Framework for Cultural Statistics. Montreal: Author.

http://uis.unesco.org/sites/default/files/documents/unesco-framework-for-cultural-stat istics-2009-en 0.pdf

Werther, W. B., \& Chandler, D. (2014). Strategic Corporate Social Responsibility: Stake- 
holders, Globalization, and Sustainable Value Creation (3rd ed.). Thousand Oaks, CA: SAGE Publications, Inc.

Yates, D. (2016). Museums, Collectors, and Value Manipulation: Tax Fraud through Donation of Antiquities. Journal of Financial Crime, 23, 173-186.

https://doi.org/10.1108/JFC-11-2014-0051 